\section{Cardinal Near Rosetown}

MRS. TED SCRIVENS, Rosetown

A beautiful Cardinal (male) was en on July 9, 1957 perched on the ranch of an evergreen at our farm ome 18 miles northwest of Rosetown. his spruce is growing about twelve et from the window so the Cardinal uld be very clearly seen. It stayed bout five minutes, and was not en again.

\section{ewis's Woodpecker ai Keatley}

A. P. Pym reports a Lewis's Woodcker spending the first three weeks October in his garden at Keatley. was still there feeding on the abapple crop when Mr. Pym gave this report at the annual meeting October 18.

\section{New Saskatchewan Species}

"The Parasitic Jaeger in Saskatchewan," by Charles D. Bird, Canadian Field-Naturallist, Vol. 71, Jan.March 1957, p. 37, lists a sight record of this species for Lozinsky's Slough, 9 miles south and $1 \frac{1 / 2}{2}$ miles west of Kindersley, cn June 27, 1956. It also lists two records furnished by Fred G. Bard of the Saskatchewan Museum of Natural History: one suffering from botulism taken at old Wives Lake by George Lydiard, on Sept. 1 (or Sept. 19), 1933; and a specimen shot by Mr. Vinn Huggins, Oct. 28, 1933, at Imperial Belaich, on Last Mountain Lake, 7 miles east of Imperial, Sask.

The above records were overlooked and the Parasitic Jaeger mistakenly listed as "hypothetical" in the Field Checking List of Saskatchewan Birds (Bard and Houston, Feb. 1954).

\title{
Waterfowl Habitat in Saskatchewan
}

\section{By J. BERNARD GOLLOP, Wildlife Biologist, Canadian Wildlife Service}

The agencies in North America incerned with the conservation of aterfowl - particularly Ducks Unnited, provincial and state game partments, the U.S. Bureau of port Fisheries and Wildlife and the anadian Wildlife Service-are curnitly trying to do something about e problem of the destruction of the ntinent's wetlands. Their most urnt task is to draw up a plan to unteract drainage that will prove be unwise in the long run, all of e public's interest being considered. One phase of this plan is to evalue the waterfowl habitat currently ailable in order to determine which pe is most valuable and which is ost urgently in need of being saved. his evaluation includes an inventory lakes and sloughs, followed by derminations of waterfowl use the ar round, and of potential drainage d drought.

In Saskatchewan, spring and sumer inventories and waterfowl use prairie water areas can be dermined from data gathered in the urse of aerial breeding pair and ood surveys conducted by the Saskchewan Wildlife Branch and the S. Bureau of Sports Fisheries and
Wildlife for the purpose of setting hunting regulations. Ducks Unlimited has begun a more detailed ground survey that will eventually cover the southern half of the province.

The missing link is the Septemberto-December period. We know that Saskatchewan has probably the best hunting in North America, but we do not have a catalogue of the sloughs and lakes that provide this hunting, nor do we know the relative values of these areas. As a start on this phase of the project the Canadian Wildlife Service is asking the cooperation of meinbers of the Saskatchewan Natural History Society. In the centre of this issue of the BLUE JAY there has been inserted a form that we would like you to fill out and return to us. The form is pretty well self-explanatory, but we would like to emphasize that right now we are interested in areas that have been heavily used by waterfowl in the past couple of years.

We shall very much appreciate any assistance that members may be able to give us in this project. If you yourself are not in a position to fill out the form, possibly you would be good enough to pass it on to someone who is. 